Article

\title{
Promoting Sustainability through Investment in Building Information Modeling (BIM) Technologies: A Design Company Perspective
}

\author{
Marius Reizgevičius ${ }^{1,2}$ (D), Leonas Ustinovičius ${ }^{3, *}$, Diana Cibulskienè ${ }^{2}$ (D), Vladislavas Kutut ${ }^{1}$ \\ and Lukasz Nazarko ${ }^{3}$ (D) \\ 1 Department of Construction Management and Real Estate, Vilnius Gediminas Technical University; \\ 11 Sauletekio al., 10223 Vilnius, Lithuania; mariusreizgevicius@gmail.com (M.R.); \\ vladislavas.kutut@vgtu.lt (V.K.) \\ 2 Siauliai University, 88 Vilnius Street, 76285 Šiauliai, Lithuania; cibulskiene@yahoo.de \\ 3 Faculty of Engineering Management, Bialystok University of Technology, 45A Wiejska Street, \\ 15-351 Bialystok, Poland; 1.nazarko@pb.edu.pl \\ * Correspondence: 1.uscinowicz@pb.edu.pl; Tel.: +370-5-2745-233
}

Received: 3 January 2018; Accepted: 14 February 2018; Published: 26 February 2018

\begin{abstract}
The aim of this article is to enhance the understanding of how design companies perceive the benefits of Building Information Modeling (BIM) technologies application. BIM is recognized in the literature as a (potentially) powerful driver leading the construction sector towards sustainability. However, for design companies, the choice to invest in BIM technologies is basically an economic one. Specifically, a design company assesses economic benefits and efficiency improvements thanks to the application of BIM technologies. The article discusses the return on investments (ROI) in BIM technologies and reviews ROI calculation methodologies proposed by other authors. In order to evaluate BIM return on investment correctly practical ROI calculations are carried out. Appropriate methods, together with the relevant variables for ROI calculation, are developed. The study allows for adjusting the calculation method making it more accurate and understandable using the Autodesk Revit based ROI calculation of the first year.
\end{abstract}

Keywords: building information modeling; BIM; sustainability; sustainable design; return on investment; ROI; efficiency; BIM evolution

\section{Introduction}

Building Information Modeling (BIM) technology has radically altered the organization of construction operations. Building information models and digital construction allow for assessing building structure and to identify its advantages and disadvantage, taking into account technological, economic, and environmental aspects. It is widely believed that the popularization of BIM should have a positive impact on the sustainability of the whole construction sector [1]. Representatives of the construction industry base their decisions to invest in BIM on its expected impact on the construction project performance. Therefore, the evaluation of quantitative and qualitative benefits of BIM is necessary. In this paper, the analysis of the concept of Return on Investment (ROI) and of ROI calculation methodologies are carried out. Significance of the criteria of the ROI is assessed. Data on cost reduction thanks to BIM implementation is scarce, with design data confidentiality being one of the primary reasons. Published studies are often criticized for scope, accuracy, calculations, objectivity, and general bias (in cases when studies are published by companies selling BIM-related software and services) [2].

There are very few frameworks and examples of ROI calculations relation to design processes. The results generated by the most common ROI tool, Autodesk Revit evoke certain doubts (analyzed 
later in the paper), therefore, the authors have decided to develop an alternative method of ROI calculation that would be suitable not only to market giants, but also to small and middle design studios.

The goal of this paper is to analyze the benefits of BIM technologies application in design companies. Specifically, the application of ROI approach to measuring BIM efficiency is studied based on the current body knowledge. An applicable ROI calculation model is also proposed. Regarding the research methods, the authors first performed the analysis of the scientific literature on the ROI concept and on measuring BIM efficiency [2-9]. Then, the logical construction approach is used to propose a specific ROI calculation method. Finally, the application of the method is presented based on the data from a Lithuanian design company.

\section{Building Information Modeling and Sustainability}

Building Information Modeling may be described as a process of: (a) elaborating an integrated and holistic building creation strategy encompassing design, construction, and life-cycle management based on modelling and computer simulation [10]; (b) creation and utilization of system of integrated graphical data management and information flow in connection with the description of construction process; and, (c) turning single contractors into teams that work as decentralized units that tackle complex problems and integrate separate tasks into coherent processes. In consequence, an increase in the efficiency and the lowering of costs of various operations throughout the entire building lifecycle is expected [11].

Conventional three-dimensional (3D) BIM is being transformed into a four-(4D) [12], five-(5D), six-(6D), or even seven-(7D), and, in the future, eight-dimensional (8D) versions on the basis of the application of PLM (Product Lifecycle Management) to construction [13,14]. This solution has been named BLM (Building Lifecycle Management) or unified project management [15]. This trend is a logical consequence of the use of large amounts of information available in smart 3D building models [16]. Synthesis of aspects integrated in the BIM framework is presented in Figure 1.

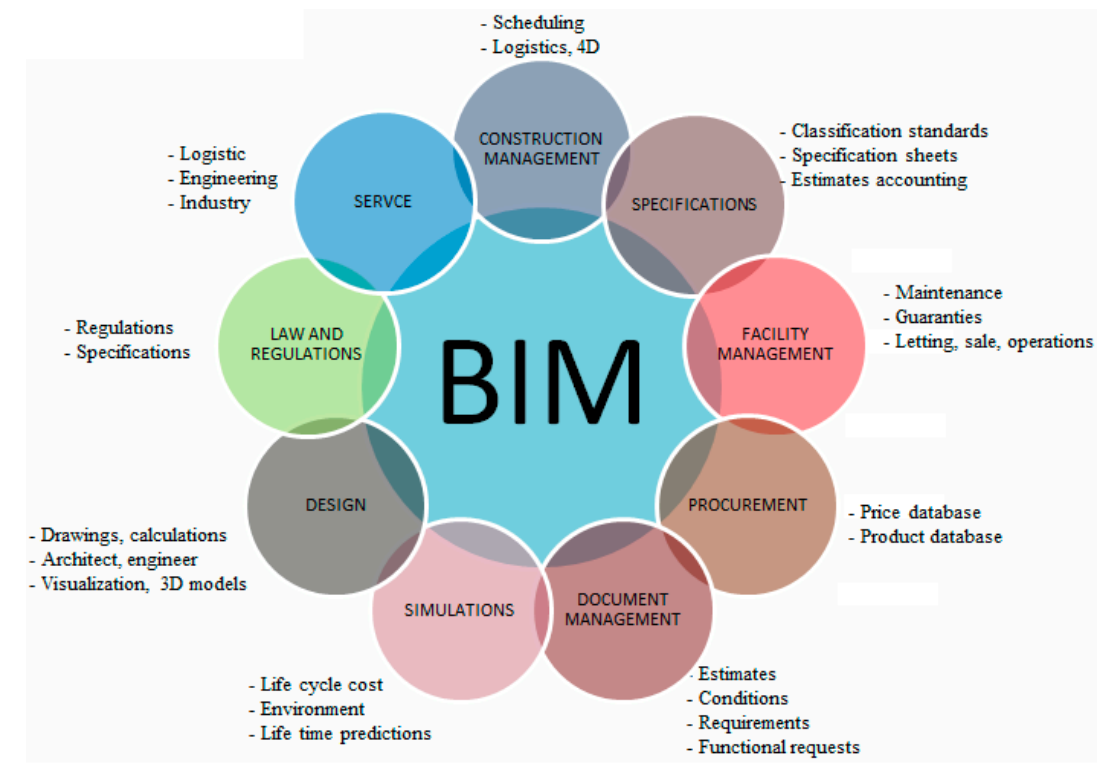

Figure 1. Building Information Modeling (BIM) lifecycle view [17].

The BIM dimensions beyond the third one may be described as [17,18]:

- $4 \mathrm{D}$-virtual model of the built structure with construction plans and work progress control capability; with additional possibility to prospectively visualize a virtually constructed building in any moment in time; 
- 5D—cost data is fed into a 3D model coupled with the construction schedule. Benefits of the fifth dimension of BIM may consist in the higher precision and predictability of changes occurring in the project together with a more reliable cost analysis of different construction scenarios.

- 6D-introduction of sustainable development principle into the investment process with an emphasis on energy efficiency. The sixth dimension of BIM allows for obtaining information about the building's projected energy consumption at a very early (concept) stage.

- 7D-integration of the Facility Management concept into BIM. It allows tracking of the status of given building components, their specifications and guarantee periods. The seventh dimension of BIM encompasses the management of the full life cycle of a building from the concept to the demolition.

- $8 \mathrm{D}$-supplementing the model with security and healthcare information. This dimension focuses on three tasks: identification of threats resulting from chosen design and construction solutions, indication of alternatives to the most risky solutions, signaling the need to control specific risks on the construction site.

From the position of sustainability paradigm, the evolution of BIM promises many possible ways in which designing, constructing, maintaining, and decommissioning buildings may be done in a more sustainable manner. Most commonly, the positive impact of BIM implementation on the sustainability of the construction sector is expressed through the concept of sustainable (green) design [19], which may be defined as creating and operating a healthy built environment based on resource efficiency and ecological design [20]. Additionally, wider spread of BIM technologies is expected to have a positive impact not only on environmental aspects of sustainability, but also on economic and social ones. It may be stated that BIM promotes sustainability in its three classical dimensions:

- Environmental sustainability-more environmentally conscious decisions throughout the whole life cycle of a building. Thanks to the BIM's capacity to store, process, and share all kinds of building-related information it is possible to minimize environmental impact of the asset in relation to: energy and water consumption, used materials, waste management, carbon footprint etc.

- Economic sustainability—assuring economic viability, increasing productivity, and reducing waste. Most authors concentrate on the economic benefits that BIM poses for investors in terms of early detection of potential clashes, better engineering decisions, more efficient logistics, precise ex-ante calculation of costs throughout the whole life cycle of an asset, etc. This paper studies the question of economic viability of implementing BIM technology in design companies since this topic is currently insufficiently covered in the literature.

- Social sustainability—contributing to creating healthy and livable communities by providing tools to improve building operation in such aspects as: waste management, indoor air quality, noise pollution, safety at the construction site, more precise, and less disturbing operations on municipal infrastructure, onerousness of maintenance activities (thanks to better timing and synchronization). Moreover, sustainability-related information continuously gathered and analyzed thanks to BIM may be turned into an instrument of social engagement by involving occupants in setting common sustainability goals for their buildings, monitoring the progress, and celebrating achievements. Such use of BIM does not only contribute to "greening" of the built environment, but also encourages interaction among occupants and strengthens social bonds.

By modelling, managing, and predicting such aspects of construction as waste management, indoor air quality, protection during construction, erosion, and sedimentation control, etc. All of that is related to gathering, storing and processing large amounts of specific data that needs to be treated in an integrated way just the way BIM does it [20]. In other words, BIM's contribution to sustainable design could be summarized in five points [21]: better informed decision-making, better analysis, easier access to information, better communication between stakeholders, and simpler certification. It is therefore in the public interest that as many designers as possible adopt BIM technologies in their practice. 


\section{Benefits of Implementing BIM in A Design Company}

Yan and Damian [22] carried out a study to assess building information model implementation advantages and barriers. The aim was to assess the ratio of BIM in architecture, engineering, construction, management companies of the United Kingdom, the United States, and other countries [23-26]. Companies that were not using BIM were questioned as well. The questionnaires of BIM implementation barriers were sent to the Architecture, Engineering and Construction (AEC) industry practitioners and academics. USA is the undisputed leader in BIM use. Besides USA, only few UK companies use BIM technology; feasibility studies are still in process. However, local government stated that by 2016 all public sector construction projects should be carried out using 2nd BIM competence level $[27,28]$.

21 respondents (out of 67 questioned) were from UK, 23 from USA, and 23 from other countries [22,29]. $25 \%$ of respondents in the US and UK noted the biggest advantage of BIM to be short designing time. $25 \%$ of respondents in the United Kingdom assumed it to reduce costs and human resources. More than $10 \%$ of respondents of both the countries believed that BIM technology advantages were: creativity, sustainability, and increased quality. About $40 \%$ of US respondents and $20 \%$ of UK respondents believed that their firms would have to use a lot of time and human resources for training. It was emphasized that decisions taken by organizations were based on business prospects (profit). AEC industry is hesitant to invest in BIM because of the lack of information about BIM financial benefits. In addition, social and personal work habits of architects and designers need to be assessed. Designers are usually satisfied with their work quality and any changes are not easily acceptable. Other barriers were also mentioned: currently used technologies (software, skills) are sufficient; workers refuse to be trained, BIM is not suitable for all projects; expensive training and uncertain copyright ownership.

According to McGraw Hill Construction BIM studies two thirds of users foresee positive ROI on their investments. Almost half of the users (48\%) get the average ROI indicator. Users that appreciate BIM identified key factors affecting the use of BIM software [3]:

(1) improved project results (less requests for information (RFI) from customers),

(2) more efficient cooperation using 3D visualizations,

(3) personnel productivity improvement,

(4) the positive impact on winning new contracts,

(5) BIM lifecycle value, and

(6) initial staff training costs.

The authors have conducted supplementary survey among design companies to determine the most important qualitative benefits of implementing BIM. Respondents were asked to indicate which charactersitcs of BIM would be most important in the decision to start using BIM software. The following features were listed:

(1) user-friendliness,

(2) easy sharing of information in one central file,

(3) ability to perform automatic analyses (lighting, building's location in relation to cardinal directions etc.),

(4) transparency of projects,

(5) detailed visualisations,

(6) better conditions for designing prefabricated elements,

(7) precise calculation of the needed amount of work,

(8) more possibiities to innovate, and

(9) avoidance of errors.

According to McGraw-Hill Construction studies [5], 27\% of the potential BIM users in Western Europe are not interested in BIM software due to the economic factors. Western European countries 
carry out much lower volume projects; existing projects are often reconstructed/modernized causing less favorable environment for BIM. According to the survey [5] 70\% professional users use BIM for more than $60 \%$ of their projects. Meanwhile, $46 \%$ of new BIM users building information model use it in about $15 \%$ of their projects. Taking all Western European BIM users into account, 59\% use BIM software in more than $30 \%$ of their projects. In conclusion, those users who have comprehended the essence of BIM have effectively integrated it into their internal design processes [30].

Finnish national authorities, local governments, and representatives of industry begin to appreciate opportunities that follow BIM implementation [27]. The guide of general requirements of BIM, published in 2012, highlighted the increasing need to develop general rules and standardized BIM. Initial mandates and requirements were only for building designs, but in 2015, general requirements for infrastructure projects were issued [27,31]. In many countries around the world one observes the promotion of BIM use at governmental levels [32].

BIM Institute of Canada suggested that BIM designing should be binding in the country's public sector. The authors [33] state the inability of the responsible organizations to standardize and patent BIM operation to be the dominant factor for BIM installation in public sectors. Standards and protocols of common language, as well as software packages that can interact with each other, are necessary in order to make the information freely available to all construction market participants.

BIM benefits within the building lifecycle are identified by processes according to "Digital Construction" guidelines for 2014-2020 [34] by Lithuanian construction organizations: improved new spatial planning and design, fewer mistakes, and more rational decisions. Design process is of higher quality and more rational, there is less need for amendments in the future [35,36]. BIM model visualizes design solutions of all design parts, for the client to gain more understanding of the results, eliminating mistakes caused by the overlapping parts of the project [37-40]. According to the theory [41], different BIM use scenarios show BIM network to be effective in reducing the number of mistakes. Mistakes resistance mechanism: permanent and direct communication (in real time), accident detection, automated scrutiny of standards/codes, design versatility, and continuous learning are compelling reasons reducing the number of design defects. According to the authors, further research is necessary to verify the theoretical studies carried out by other authors.

There is no widespread method of BIM return on investments (ROI) calculation. Most of the users regard ROI as time, money, and BIM deployment effort return [6]. Calculated ROI rate is an estimated payback of BIM software, but it is not a return on investment in a specific project. Negative or equal ROI is noticeable in smaller organizations during the first year of primary BIM mastering stage, as it is harder for the organization to absorb the initial costs because of the software price, training, and business development using BIM. Main beneficiaries of the projects that use BIM design are designers and contractors [42]. Usually contractors reach positive ROI faster than designers because they get more financial benefits-less duplication of work, increased profits. The highest ROI is achieved by users with a longer experience in BIM use, strong skills, years of experience, a high level mastering BIM [6]. According to Poirier [43], investment in new equipment and technology may improve productivity but productivity indicators may actually decrease if the price of new equipment is greater than relative savings as a result of labor costs and profit results. BIM implementation creates a challenge that can be met only if BIM technologies are profitable for a company and the profit potentially outweighs the implementation costs. In the next part of the paper, ROI in BIM technologies are calculated as compared with "Autodesk Revit" ROI calculations.

\section{Research on Economic Effects of BIM-Based Design}

According to the review of latest literature there are several methods that could be used to analyze the investment in BIM technologies. The best known is the return on investment analysis (Return on Investment-ROI), "Prioritaring Efter NyytoGrunder" (PENG) model and total economic impact (TEI) model. ROI analysis of few projects is performed by the Center for Integrated Facility Engineering (CIFE) [1]. ROI of the first year is also calculated by Autodesk Revit company. PENG model is used 
in the Swedish construction industry to calculate savings using BIM. TEI model, used by CIFE, is to evaluate the impacts of the Virtual Design and Construction (VDC) and to calculate the payback time. Azhar's [44] research indicates that BIM technology return on investment (ROI) may be much higher than traditional construction projects without BIM showing potential economic benefits [45].

Research of Al-Zwainy at el. [46] show that BIM return on investment can be analyzed in various aspects. CIFE performs ROI analysis in Holder Construction Company. It makes solid ROI calculations of 10 projects of BIM technologies and assesses the savings. Comparative studies of two options are often performed: two similar projects are estimated (one designed using BIM, the second one designed with traditional methods). Autodesk Revit has developed the first year of ROI (return on investment) calculation model evaluating software and labor costs, loss and growth of productivity, as well as training time. CIFE uses the total economic impact model (TEI) to find out the benefits of digital design. This method is based more on BIM payback time [3].

Return on investment in BIM was estimated in the United Kingdom, France, and Germany [6]. $71 \%$ of UK consumers receive a positive return on investment ( $37 \%$ of users get $25 \%$ or bigger return on investment) and $13 \%$ of consumers get negative ROI. Out of the three studied countries, the percentage of consumers with negative ROI is the highest in the UK. In France, the positive ROI is observed by $82 \%$ of the users and the negative ROI ratio only by $5 \%$ of the users. Positive ROI is obtained by $67 \%$ of consumers in Germany (the lowest result out of the three studied countries) and $9 \%$ register negative ROI. $55 \%$ of the companies that do not use BIM software state that the first reason for not using BIM is no such requirement from the clients. They also add time requirements to evaluate the appropriate software and the scale of investments as the reasons. Small businesses in Western Europe are in no hurry to apply BIM technologies because BIM is less effective for smaller projects. Based on the last AEC field studies BIM also brings new challenges [47]. Very often, models become so large and complex that they exceed the capacity of the computers, making it problematic to track the models in real time.

Study of Giel and Issa [48] suggest that return on investment in BIM-supported projects may be much higher than the return from the traditional investments. Works [49-52] describe the benefits from BIM implementation in the qualitative terms. Some papers based on statistics on establish ROI in quantitative terms $[45,48]$. These studies conclude that short-term and small contracts may benefit from BIM in some qualitative aspects, but monetary savings related to BIM implementation were relatively low. The analysis of ROI also indicated that the design costs would rise if they were to operate with BIM [45]. It is an understandable result of more workload imposed on designer(s) by BIM in the initial project phases. It is the owner (investor) and contractor who may count on the largest gains from implementing BIM. This observation is confirmed by the case studies presented in [53]. The study [54] proposes a structured method for analyzing the BIM ROI based on the avoidance costs of rework due to design errors.

Method of calculating ROI proposed by Autodesk evaluates not only the cost of the system, but also the productivity changes [55]. A sharp decline in productivity is noticeable when the new system is acquired, as users have to learn to use new program. After training and the time needed to master the program, the curve of productivity noticeable goes up (Figure 2).

ROI in BIM technologies could not be measured from design to construction completion or demolition. Construction companies that are unwilling or unable to create their own design departments are often BIM initiators by requiring it from external designers that they work with. Meanwhile, a designer looks for the profitability of the offered services. Designer's work starts from the design task and the preparation of a commercial offer, and ends with a construction permit and project acceptance certificate. Construction contractor usually appears only when the construction permit is ready. The construction contractor, as well as the designer, are often chosen in the basis of the lowest price criterion. Assessing ROI, the return curve may be significantly distorted. Taking the period from the design to construction completion is one way to calculate the return. Designer does not care for the end of construction works if it has no author supervision of the execution or technical 
supervision contract, so ROI should not be measured the same for design and construction companies. BIM design should not be forced on designers-it has to be implemented on a voluntary basis and is consistent with the designer's whole work system.

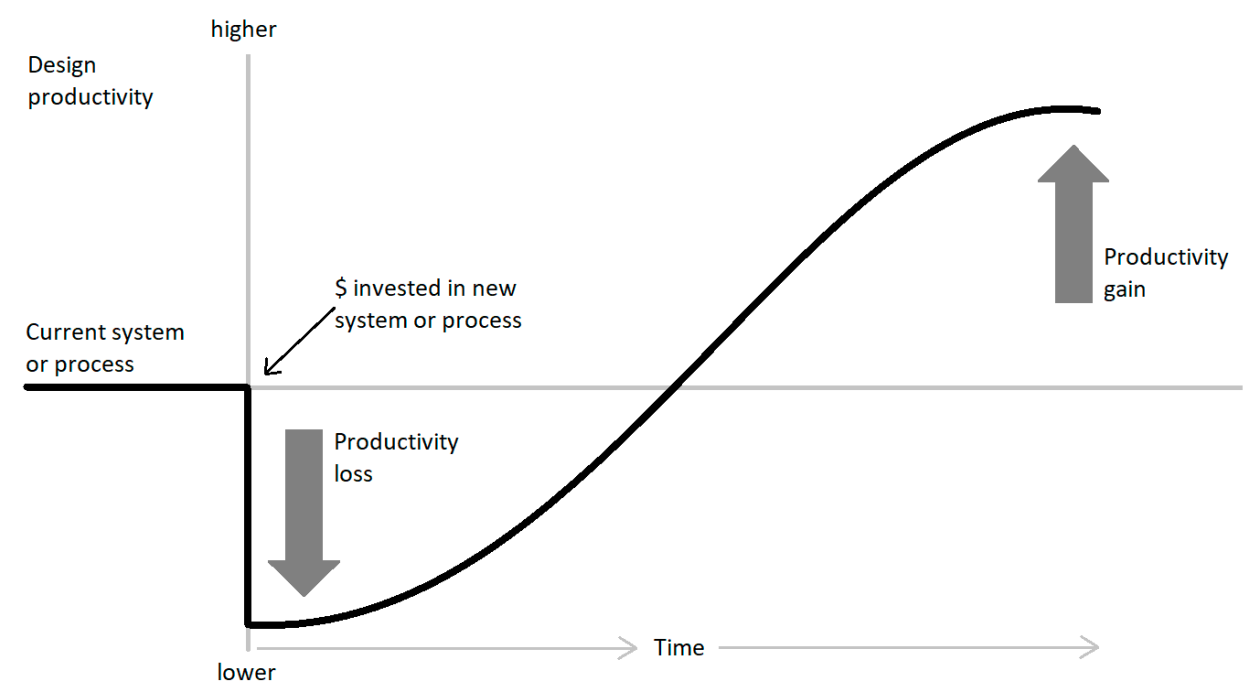

Figure 2. Design productivity after BIM system implementation [56].

In the process of assessing the benefits of BIM, it is important to mention the wider communication and cooperation opportunities of the staff and of individual members of the project team [57]. BIM establishes closer cooperation between members of the project team. BIM-integrated interactive possibilities are much more favorable to the customer information. Database information of building information model may be freely accessible via the internet and shared using cloud technology between members of the design team, customers, suppliers, producers, etc. [57].

Figure 3 illustrates the links between the customer (builder), construction contractor, and the designer (design company or architect) [58]. Such lines of communication are described by the standard design company model. Contractor search starts when the project is ready. It is noted that instructions from the customer are directly transmitted to the construction contractor that coordinates construction issues with subcontractors, suppliers, and other participants in the construction works. In this configuration, the designer is left aside and only cooperates with the client who implements designer's instructions [59]. This model provides a hierarchical management system where separate participants of the construction project are in no contact; there is no cooperation between different parties. Most design companies work according to this model, therefore a fair assessment of ROI is debatable. Contractor, designer, customer-different parties are mostly concerned about their own, narrowly understood interest.

Autodesk Revit calculates ROI, i.e., the indicator characterizing the return on investment required for BIM technologies installation, in the following manner [55]:

$$
R O I=\frac{\text { Earnings }}{\text { Investmentor Cost }} .
$$

The first year, ROI calculation is the following:

$$
\text { First year } R O I=\frac{\left(B-\left(\frac{B}{1+E}\right)\right) \cdot(12-C)}{A+(B \cdot C \cdot D)} .
$$

ROI formula variables:

A- cost of hardware and software (EUR) 
B- monthly labor cost (EUR)

C- training time (months)

D- relative productivity loss during training in relation to the productivity before the training (percentage)

E- relative productivity gain after training in relation to the productivity during the training (percentage)

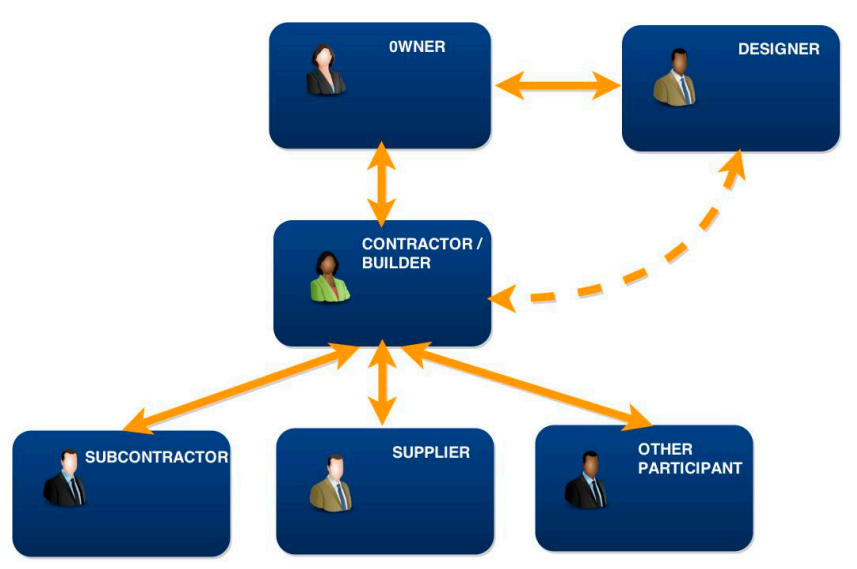

Figure 3. Standard cooperation model between construction parties.

The question is whether ROI calculation method by Autodesk assesses all the relevant variables. When calculating the return on investment the following elements should be considered:

1. The software and hardware

2. Training

3. Development processes

4. Interoperability solutions

5. 3D library development

6. Consultant services

The authors suggest a different methodology of ROI calculation ("ROI-DC") which takes into account more variables. The proposal of first year ROI verbal formula expression is the following:

$$
\text { ROI DC }(\text { first year })=\frac{(\text { Gain after Investment }- \text { Investment Cost })}{\text { Investment Cost }} .
$$

As the next step the following ROI formula is proposed:

$$
\text { First year ROI DC }=\frac{((12-C) \cdot(1+E) \cdot(B \cdot F \cdot G)-(A+(B \cdot C \cdot D)}{A+(B \cdot C \cdot D)} .
$$

1. Increase (Gain) after investment $=(12$ months - training time (months $)) \times$ relative productivity gain 12 months after training in relation to the productivity during the training (times) $\times$ monthly labor costs (euro) $\times$ direct design work (times) $\times$ company works specificity (times).

2. Investment Price (Cost)-software price + (training time (months)) $\times$ monthly labor costs (euro) $\times$ relative productivity loss during training in relation to the productivity before the training (times).

Visualization, productivity increase, process improvement (less duplication of work and fewer coordination problems), competitive advantage, improvement of communication, and collaboration [5] 
are important issues to consider while assessing the return on investment in BIM. In order to assess the benefits of BIM and to assess the return on investment it is necessary to take into account the following factors: what savings the new system will make, what influence it will have on the company's share value and profitability, how much time it will take to train new users [48].

Some of the variables in the formula have bigger weight than others. ROI calculation methodology by Autodesk [55] shows that the productivity index (deriving from the productivity gains and losses) has the greatest impact on ROI. The results also show that the most productive were the users, who have been trained from the scratch and had no contact with the program before. Productivity of the consumers who purchased the program and independently studied it does not equal the one achieved by the fully trained users. Staff with no training were the least productive. The data shows that the critical training time is 1-2 months. If the trainings start within two months after purchasing the program, bad habits develop and incorrect program use jeopardizes the productivity [55].

Figure 4 indicates the areas of ROI measurement. The fact that ROI cannot be measured in only one of those areas is underscored. The figure shows that the building information model is most beneficial to the customer through the entire lifetime of the construction. The customer has the longest payback time. Meanwhile, for the designer/architect who uses BIM model only for the designing time, the payback time for the particular project is much shorter. BIM payback time for contractors is slightly longer so they feel bigger benefits of BIM. Other construction participants, such as suppliers, subcontractors, etc., are involved in the project only partially, and therefore ROI time for them is even shorter.

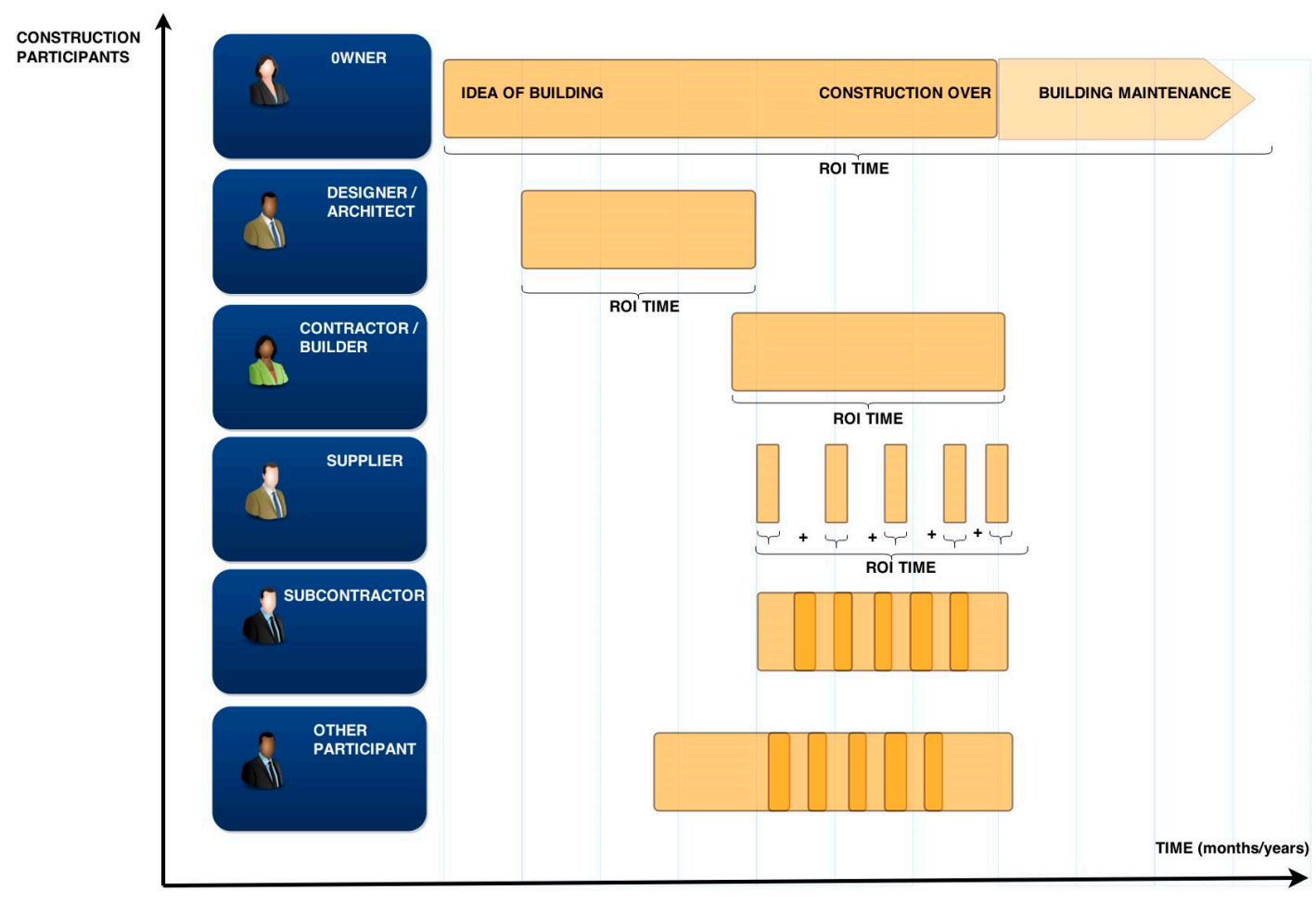

Figure 4. Return on Investment (ROI) assessed areas [50].

\section{Evaluation of ROI in BIM Software}

Different actors in the construction project have different needs that may be satisfied by BIM (Figure 5).

The analysis of existing research and calculations of BIM technologies return on investment by various authors and companies have shown that the advantages of high ROI in BIM technology has not persuaded many design firms and that they are in no hurry to implement the building information 
model software. A number of reasons have led to this situation. In particular, ROI calculations are carried out for large projects where BIM is used not only in design, but also in construction and management. High ROI ratio seems inadequate when calculation parameters exceed $100 \%$ of the first year of BIM software installation. Such indicators seem inadequate and they describe only construction industry giants-design centers, consortia, companies engaged in both the design, and construction activities. A medium or small design company only engaged in design will certainly not experience such a high first year return on investment (ROI $\geq 100 \%)$. The existing projects will suffer first of all because of staff training, large investments requiring a loan that will effect in paying back the interest afterwards.

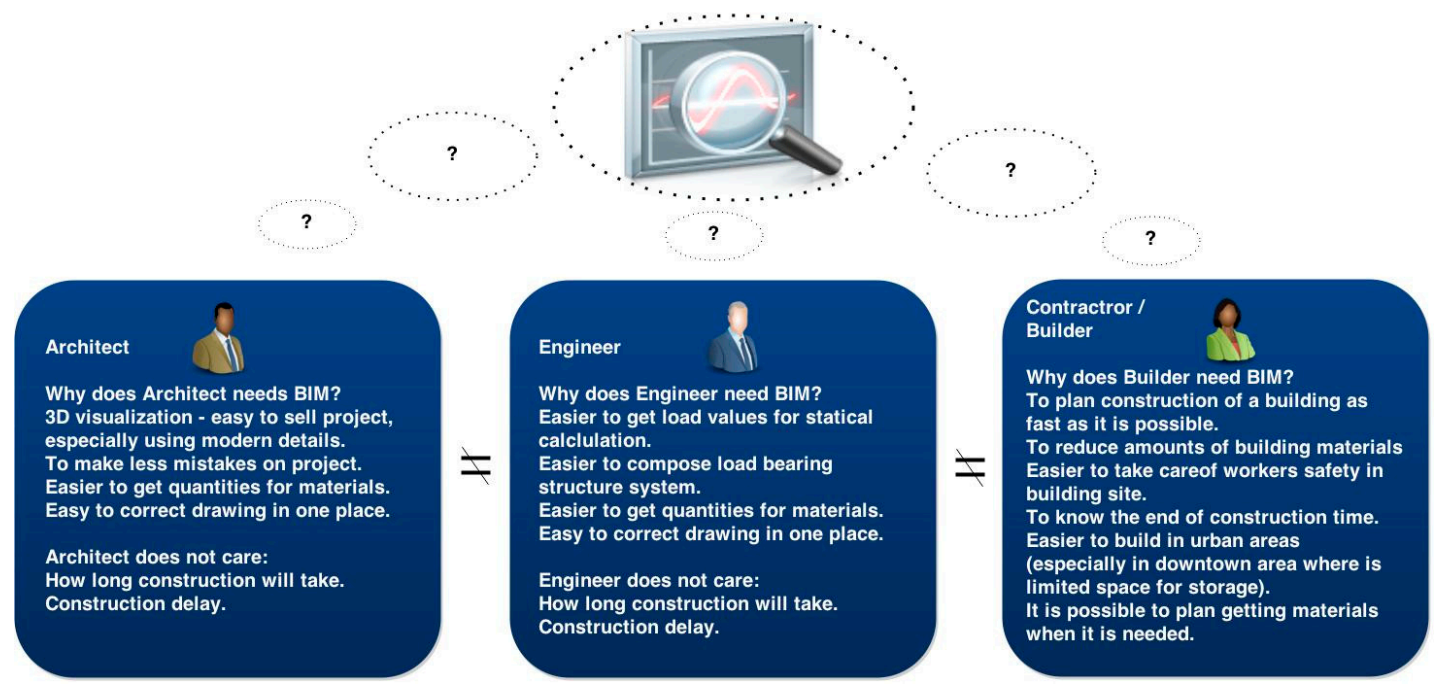

Figure 5. Different needs of participants in a construction project [59].

In order to evaluate the return on investment in BIM correctly designers of companies that installed BIM software were interviewed. The results are shown in Table 1.

Table 1. Results of the survey of designers who have installed BIM software.

\begin{tabular}{cc}
\hline Expected productivity loss after starting to use BIM software & $34 \%$ \\
\hline Time needed to restore efficiency to the previous level & 2.3 month \\
Maximum productivity gain after staff training & $31 \%$ \\
Time period for the productivity to reach the maximum level & 4.8 month \\
\hline
\end{tabular}

ROI calculation methodologies that are presented by other authors show that there is a number of criteria (variables) to be assessed in order to correctly calculate the return on investment. Known BIM return on investment calculations show that not all of the relevant variables are evaluated. In addition, it needs to be pointed out that ROI rate of first year BIM exceeding $100 \%$ should be seen as inadequate. The same numerical values of ROI indicators are not obtained after replicating the calculations of the model, which raises the questions whether the calculations were correct, whether they reflect the reality, and whether there are any hidden variables in the formula. Since the detailed calculation process is not revealed the ROI calculator subtleties are impossible to clarify. In addition, it is necessary to consider the fact that every country has different working conditions, wages, and different possibilities for big and small companies. The adjusted ROI calculation formula is presented in this paper based on the existing studies of BIM return on investment.

Design company analysis is performed in order to assess the benefits of BIM. A small design company operating for more than two years is assessed together with its architects, engineers, and energy performance certification experts. The evaluation of various software configurations 
is aimed at finding a combination of programs or a program that will suit both the architect and the engineer work. Research may also be useful for new or recently started companies.

Three design software distributing companies were interviewed. There are two alternatives on which BIM introduction for a company is based: Autodesk and Archicad. In order to get more comprehensive results an alternative is introduced-ZWCAD + Professional software that does not have a BIM design possibility. It is important to mention that the ZWCAD design program is an alternative to AutoCAD. This software does not require additional money for qualification and training. Autodesk company, as the dominant player in the field of design software, sells its products grouped into packages. Autodesk offered package includes the following programs: AutoCAD, AutoCAD Architecture, AutoCAD MEP, AutoCAD Structure Detailing, Autodesk Showcase, Autodesk Revit, Autodesk 3ds Max Design, Autodesk Raster Design, Autodesk ReCap, Autodesk Navisworks Manage, Autodesk Inventor, Autodesk InfraWorks, Autodesk Robot structure, and Analysis Professional (design calculation software). ArchiCAD software package also includes software add-ons: BIM Server, BIMx, and Eco Evaluation (power rating). It is noted that the large sets of programs offered are in the excess in respect to micro or small companies with few employees that do not engage in big projects. In the best case, the company will use $2-3$ programs from the package. Nevertheless, the design company is the limited on the grounds that the purchase price for the entire software package or a program will remain the same.

In case of an enterprise that is engaged only in a fragment of the whole construction project, like designing a building, BIM benefits are difficult to assess. The method of ROI calculation that is presented in this paper is tailored to address the design phase with its specificity. The following issues in a design company implementing BIM technology have been identified:

1. purchasing software with required functionalities,

2. expectation of improved results after BIM implementation,

3. slowing down of the design process directly after BIM deployment, and

4. training time after the deployment of BIM tools,

Determining a company's specificity.

All of these issues are reflected in the coefficients that need to be determined before ROI in BIM in a design company. Autodesk Revit offers a similar calculation method, however, the use of the formula visible in the provided Excel file does not give the same results as Autodesk Revit. That suggests that there might be some hidden coefficients built into the Autodesk Revit formula.

The coefficients of ROI-DC methodology have been established as a result of interviews with project staff in design companies, which have implemented and use BIM design. F and G coefficients (direct design work, company's work specificity) are to be calculated individually for each design enterprise planning to invest in BIM technologies.

Table 2 contains three alternatives of software that are analyzed to choose the optimal version for a micro company. The table summarizes data for two positions (architect and designer). It is noted that the proposed duration of the training is relatively short -24 to 40 academic hours $(0.6-1$ working week). In general, this is believed to be a marketing tool allowing for the user to understand that the management of the program is easy enough to learn in such a short time. It is necessary to assess the size and number of projects, the need of BIM for projects, computer settings in order to choose the right alternative for optimal work. If the capacity of a computer is insufficient it needs to be improved or new ones have to be purchased to meet the needs of more demanding programs. 
Table 2. Evaluation of software configuration alternatives in a micro enterprise design company.

\begin{tabular}{|c|c|c|c|c|c|}
\hline Alternative & $\begin{array}{l}\text { Cost of the } \\
\text { Program, } € \\
\text { (with Taxes) }\end{array}$ & Computer Settings & $\begin{array}{c}\text { Cost of the } \\
\text { Annual } \\
\text { Subscription, } €\end{array}$ & $\begin{array}{c}\text { Suggested } \\
\text { Training Time, } \\
\text { Hours }\end{array}$ & $\begin{array}{l}\text { Cost of the } \\
\text { Training for } 1 \\
\text { Person, } €\end{array}$ \\
\hline $\begin{array}{c}\text { I } \\
\text { (architect work } \\
\text { place) }\end{array}$ & 4485.64 & $\begin{array}{c}\text { 64-bit operating system } \\
\text { 4GB RAM internal } \\
\text { memory } \\
\text { Processor: dual-core }\end{array}$ & 588.74 & $40 / 1$ workplace & $\begin{array}{c}173.77 \\
(4.34 € / \text { hour })\end{array}$ \\
\hline II & 562.0 & $\begin{array}{c}\text { 1GB RAM internal } \\
\text { memory } \\
\text { Processor: } \\
\text { Intel }{ }^{\circledR P e n t i u m ~} 41.5 \mathrm{Ghz} \\
\text { or equvalent AMD } \AA\end{array}$ & 242.0 & Unnecessary & Unnecessary \\
\hline $\begin{array}{l}\text { III } \\
\text { (architect + } \\
\text { engineer } \\
\text { workplace) }\end{array}$ & $\begin{array}{c}23,788.6 \\
(8349+ \\
15,439.60)\end{array}$ & $\begin{array}{c}\text { 64-bit operating system } \\
\text { 4GB RAM internal } \\
\text { memory } \\
\text { Single- or Multi-Core } \\
\text { Intel®Pentium } \AA, \text { Xeon }{ }^{\circledR} \text {, } \\
\text { or i-Series processor or } \\
\text { AMD } \AA\end{array}$ & $\begin{array}{c}3218, .6 \\
(1089.0+ \\
2129.6)\end{array}$ & $24 / 1$ workplace & $\begin{array}{c}1250 \\
(52.08 € / \text { hour })\end{array}$ \\
\hline
\end{tabular}

New variables and the calculation model is offered by the authors to assess the return on investment. "Autodesk Revit" ROI and the proposed ROI-DC (Return on Investment-Design Company) calculation models are compared. Obtained results and variables are presented for comparison. It is important to note that both models calculate the first year return on investment. Table 3 shows the ROI assessing variables. 
Table 3. ROI variables.

\begin{tabular}{|c|c|c|c|c|}
\hline $\begin{array}{l}\text { Variable } \\
\text { Symbol }\end{array}$ & ROI "Autodesk Revit" & $\begin{array}{l}\text { Numeric } \\
\text { Value }\end{array}$ & ROI "ROI-DC" & Numeric Value \\
\hline $\mathrm{A}$ & Cost of software, $\$$ & $6000 \$$ & Cost of software ${ }^{1}, €$ & $\begin{array}{c}4485,64 ; \\
562 € * ; \\
15,439.60 €\end{array}$ \\
\hline B & Monthly labor cost, \$ & $4200 \$$ & Monthly labor cost ${ }^{2}, €$ & $(713.9)$ \\
\hline $\mathrm{C}$ & Training time, months & 3 months & Training time ${ }^{3}$, months & 2 months \\
\hline $\mathrm{D}$ & $\begin{array}{l}\text { Relative productivity loss } \\
\text { during training, } \%\end{array}$ & $50 \%$ & $\begin{array}{l}\text { Relative productivity loss } \\
\text { during training } 4, \%\end{array}$ & 0.34 \\
\hline $\mathrm{E}$ & $\begin{array}{l}\text { Relative productivity gain } \\
\text { after training, \% }\end{array}$ & $25 \%$ & $\begin{array}{l}\text { Relative productivity gain } \\
\text { after training }{ }^{5} \text {, times }\end{array}$ & 0.31 \\
\hline $\mathrm{F}$ & $\begin{array}{c}\text { Used in Revit ROI } \\
\text { calculations, but direct } \\
\text { position was not found }\end{array}$ & $82 \%$ & $\begin{array}{l}\text { Direct design work }{ }^{6}, \\
\text { times }\end{array}$ & 0.82 \\
\hline \multicolumn{5}{|c|}{ NEW VARIABLES } \\
\hline G & - & - & $\begin{array}{l}\text { Company's work } \\
\text { specificity }{ }^{7} \text {, times }\end{array}$ & 0.465 \\
\hline & First Year ROI, \% & $61 \%$ & First Year ROI, \% & $x x x$ \\
\hline \multicolumn{5}{|c|}{$\begin{array}{l}\text { *-Program does not support BIM. }{ }^{1} \text { - Optimal software is chosen on the basis of its subscription costs. }{ }^{2}-\text { The } \\
\text { average salary of } 713.9 \text { EUR as of September of } 2015 \text { according to the Lithuanian Department of Statistics } \\
\text { (K2-average gross of all positions of 2015). }{ }^{3}-2 \text { months of training is set by Autodesk Revit studies as a minimum } \\
\text { training period to acquire necessary skills. Although the program distributors offer shorter training terms of } \\
0.6-1 \text { week (this is only the introduction training term that is not enough to master the knowledge). Therefore, } \\
\text { the training terms are submitted not as a training time but as the time required to achieve the same level of } \\
\text { productivity as in the use of the original software. }{ }^{4} \text { - Designers of } 10 \text { companies with the installed BIM design } \\
\text { software were questioned. }{ }^{5} \text {-Designers of } 10 \text { companies with the installed BIM design software were questioned. } \\
6 \text { - It is important to mention that this indicator of ROI calculations by Autodesk Revit in the present case does not } \\
\text { describe specific work hours-time is required not only to carry out the design work but for printing, interest in the } \\
\text { legislative framework, documentation preparation. According to ROI by Autodesk Revit } 36 \% \text { of time is spent to } \\
\text { design, } 46 \% \text { for documentation (respectively } 52 \text { and } 68 \text { hours per month), and total of ( } 36+46=82 \% \text { ) of the time for } \\
\text { general project work. As it is appropriate to evaluate this factor it is taken in the same form for calculations. }{ }^{7}-\text { The } \\
\text { opportunity of the relevant micro company to use BIM software for ongoing projects. } 46.5 \% \text { of the ongoing projects } \\
\text { needed BIM design. The company has its own business strategy to achieve the best results. Only the company } \\
\text { itself is aware of the kind of projects they work on the most often and what type of projects need BIM. Common } \\
\text { companies in Lithuania are engaged in more than one activity, i.e., they design not only new buildings, but also } \\
\text { carry out projects of reconstruction, repair and detailed plans. In some projects BIM design cannot be used and will } \\
\text { not bring the expected benefits. }\end{array}$} \\
\hline
\end{tabular}

It is important to note that other indicators could be assessed in the calculation of return on investment in BIM design:

1. number of employees for one project,

2. time consumption for the project,

3. the profitability of the project, and

4. turnover rates, etc. of the company.

For the first comparison of ROI-DC model the same measures are used by Autodesk Revit experts assessing new factor G (company specificity) in addition. The results are shown in Table 4 .

One can observe a considerable difference in the way ROI indicators are calculated. Return on investment calculation by Autodesk Revit shows the $32 \%$ of the first year costs return despite the fact that the monthly salary is six times lower than the price of the software. Logically, the rate of return seems unlikely disregarding the two variables of $F$ and G. Employee of an average salary of 714 euro per month working with BIM program would earn only 8568 euro per year and this amount is slightly above the design program cost. If in addition estimating to working with the loss of $34 \%$ in the first two to three months (i.e., 0.34 times less work done), while the remaining nine to seven months with 
efficiency increased by $31 \%$ the results of return would still be inadequate. In other words, the results are too optimistic.

Table 4. Comparison of Autodesk Revit and ROI-DC calculations.

\begin{tabular}{|c|c|c|c|c|}
\hline $\begin{array}{l}\text { Variable } \\
\text { Symbol }\end{array}$ & ROI Autodesk Revit & Numeric Value & ROI “ROI-DC” & Numeric Value \\
\hline A & Cost of software, $€$ & $4485.64 €$ & Cost of software, $€$ & $4485.64 €$ \\
\hline B & Monthly labor cost, $€$ & $714 €$ & Monthly labor cost, $€$ & $714 €$ \\
\hline $\mathrm{C}$ & Training time, months & 2.3 months & Training time, months & 2.3 months \\
\hline $\mathrm{D}$ & Productivity lost during training, $\%$ & $34 \%$ & Productivity lost during training, $\%$ & 0.34 \\
\hline $\mathrm{E}$ & Productivity gain after training, $\%$ & $0.31 \%$ & Productivity gain after training, times & 0.31 \\
\hline \multicolumn{5}{|c|}{ New Variables } \\
\hline $\mathrm{F}$ & $\begin{array}{l}\text { Used in Revit ROI calculations, but } \\
\text { direct position was not found }\end{array}$ & $82 \%$ & Direct design work, times & 0.82 \\
\hline G & First Year ROI, \% & $\begin{array}{c}- \\
32 \%\end{array}$ & $\begin{array}{c}\text { Company's work specificity, times } \\
\text { First Year ROI, \% }\end{array}$ & $\begin{array}{l}0.465 \\
-31.4\end{array}$ \\
\hline
\end{tabular}

Estimated ROI ratio shows that the design software will have no return in the first year. The resulting rate of return is negative. The difference between the required time and cost of carrying out the work is substantial. In this case, the situation of a Lithuanian company in the present market situation is assessed. The average wage of professionals working in the Lithuanian labor market is taken into account and the price of software offered in the local market is used for the calculations.

No categorical stance can be taken that there is no financial gain from installing BIM software. One of the most influential factors in ROI is wages. Wages rise while leaving other variables at fixed values would give the positive return values. Relevant calculations for a five year ROI are presented in Table 5.

Table 5. ROI in BIM in five years.

\begin{tabular}{cccc}
\hline Variable Symbol & Numeric Value & Numeric Value \\
\hline A & $4485.64 €$ & $4485.64 €$ & $1375 €$ \\
B & $1375 €$ & 2.3 months & \\
C & 2.3 months & 0.34 & \\
D & $34 \%$ & 0.31 & \\
E & $31 \%$ & 0.82 & \\
F & $82 \%$ & 0.465 & \\
G & - & ROI “ROI-DC" & $20 \%$ \\
& ROI Autodesk Revit & $57 \%$ & Ro
\end{tabular}

The model suggests that the forced installation of BIM would result in nearly doubling the prices of design services ( $714 € \rightarrow 1375 €$ ), as companies will have to pay higher salaries (thus higher earnings for the company will remain). For a simple comparison, it can be mentioned that a company $\mathrm{X}$ is currently offering an individual house project up to $200 \mathrm{~m}^{2}$ (project parts: general, architectural, construction, site plan) for $1500 €$. The company would carry out the same project for $3000 €$ in the situation of the imposed installation of BIM, and that is only in case when a company chooses one of the cheapest BIM design programs.

The performed calculation is made excluding the new $\mathrm{G}$ factor avoiding the doubt of ROI-DC calculations. These results are compared with the ROI results obtained from Autodesk Revit. $\mathrm{B}$ coefficient is the average wage of the relevant market. Calculation results are presented in Table 6.

In conclusion, the first year return of BIM installation is unnoticeable assessing $\mathrm{G}$ variable at level of current market wages and BIM software installation prices in Lithuania. It is important to mention that the second year gives better results because the employees will not lose time for trainings, work will be more efficient. 
Table 6. Comparison of Autodesk Revit and ROI-DC calculations excluding the G factor.

\begin{tabular}{|c|c|c|c|}
\hline Variable Symbol & Numeric Value & & Numeric Value \\
\hline A & $4485.64 €$ & & $4485.64 €$ \\
\hline $\mathrm{B}$ & $714 €$ & & $714 €$ \\
\hline $\mathrm{C}$ & 2.3 months & & 2.3 months \\
\hline $\mathrm{D}$ & $34 \%$ & & 0.34 \\
\hline $\mathrm{E}$ & $31 \%$ & & 0.31 \\
\hline $\mathrm{F}$ & $82 \%$ & & 0.82 \\
\hline \multirow[t]{2}{*}{ G } & - & & not evaluated \\
\hline & ROI Autodesk Revit & $17 \%$ & ROI "ROI-DC" $\quad-22 \%$ \\
\hline
\end{tabular}

Getting back to the purpose of the study — the most acceptable design software option for the company $\mathrm{X}$ is looked for. The task is to find an alternative design program for a micro company. Three options available at the market taken into account. Received commercial offers are presented in the Table 7 .

Table 7. Software evaluation alternatives for a micro enterprise in design services.

\begin{tabular}{ccccc}
\hline \multirow{2}{*}{ Alternative } & $\begin{array}{c}\text { General Program (Package) } \\
\text { Price (With Taxes) }\end{array}$ & \multicolumn{2}{c}{ Cost of One Workplace, $€$} & \multirow{2}{*}{$\begin{array}{c}\text { BIM Design } \\
\text { Function }\end{array}$} \\
\cline { 3 - 4 } & 4485.64 & Architect & Engineer-Constructor & \\
\hline I & 562 & 4485.64 & + \\
II & 20,570 & 8349 & 562 & - \\
III & & & $15,439.60$ & + \\
\hline
\end{tabular}

All three options are now compared using ROI-DC assessment methodology. With the help of a decision-making method the investment in design to the program will be made (Table 8).

Table 8. Software evaluation alternatives of a micro enterprise in design services for an architect.

\begin{tabular}{cccc}
\hline Variable Symbol & $\begin{array}{c}\text { Numeric Value } \\
\text { Alternative I }\end{array}$ & $\begin{array}{c}\text { Numeric Value } \\
\text { Alternative II }\end{array}$ & $\begin{array}{c}\text { Numeric Value } \\
\text { Alternative III }\end{array}$ \\
\hline A & $4485.64 €$ & $562 €$ & $8349 €$ \\
B & $714 €$ & $714 €$ & $714 €$ \\
C & 2.3 months & - & 2.3 months \\
D & 0.34 & - & 0.34 \\
E & 0.31 & - & 0.31 \\
F & 0.82 & 0.82 & 0.82 \\
G & 0.465 & 0.465 & 0.465 \\
First Year ROI, & $-31.4 \%$ & $481.3 \%$ & $-61.2 \%$ \\
"ROI-DC" & & & \\
\hline
\end{tabular}

Architect workplace is necessary for BIM design, so only two alternatives with BIM design capabilities are compared. The salary increase is calculated for the first year return to reach at least $20 \%$ (Table 9). 
Table 9. Software alternatives of design services for an architect (only those with BIM design opportunities).

\begin{tabular}{ccc}
\hline Variable Symbol & Numeric Value Alternative I & Numeric Value Alternative III \\
\hline A & $4485.64 €$ & $8349 €$ \\
B & $1380 €$ & $2560 €$ \\
C & 2.3 months & 2.3 months \\
D & 0.34 & 0.34 \\
E & 0.31 & 0.31 \\
F & 0.82 & 0.82 \\
G & 0.465 & 0.465 \\
First year ROI, “ROI-DC" & $20 \%$ & $20 \%$ \\
Rise in price of design services, times & 1.93 & 3.59 \\
\hline
\end{tabular}

The obtained results show that the choice of the less expensive BIM design software would raise the price of the services of the company about two times $(714 € \rightarrow 1380 €)$. Meanwhile, services that are choosing a more expensive design program can price up about four times $(714 € \rightarrow 2560 €)$. Another calculation considers BIM design programs targeted at a design engineer. The results are shown in Table 10.

Table 10. Software alternatives for an engineer-constructor.

\begin{tabular}{cccc}
\hline Variable Symbol & $\begin{array}{c}\text { Numeric Value } \\
\text { Alternative I }\end{array}$ & $\begin{array}{c}\text { Numeric Value } \\
\text { Alternative II }\end{array}$ & $\begin{array}{c}\text { Numeric Value } \\
\text { Alternative III }\end{array}$ \\
\hline A & $4485.64 €$ & $562 €$ & $15,439.60 €$ \\
B & $714 €$ & $714 €$ & $714 €$ \\
C & 2.3 months & - & 2.3 months \\
D & 0.34 & - & 0.34 \\
E & 0.31 & - & 0.31 \\
F & 0.82 & 0.82 & 0.82 \\
G & 0.465 & 0.465 & 0.465 \\
First year ROI, & $-31.4 \%$ & $481.3 \%$ & $-78.4 \%$ \\
“ROI-DC" & & & \\
\hline
\end{tabular}

When comparing design programs for engineers it is important to mention that a third alternative has the computer calculation function that facilitates the work of an engineer. Those two alternatives give an engineer the possibility to design or use BIM system for structures building modeling. Constructor work program needs additional evaluation of return to determine how much work he performs using BIM program, and what sort of building projects an engineer cannot fulfill without BIM computer calculation programs. It is therefore considered that the $G$ factor to be higher for the engineer designing special structures where special structures take the biggest part of the design.

In another option the calculation of engineer's salary at the maximum workload all year round (i.e., working without down-time). The engineer is supposed to develop only special structures requiring BIM design and construction calculations. In this case, the G factor set at level 1 and only alternative III of the software configuration used (the only that has BIM structural design and calculation functions). The desired payback time of five years is taken, i.e., the first year ROI is at least 20 percent (Table 11). 
Table 11. Software alternatives for an engineer-constructor (only those with BIM design opportunities).

\begin{tabular}{cc}
\hline Variable Symbol & Numerical Value Alternative III \\
\hline A & $15,439.60 €$ \\
B & $2200 €$ \\
C & 2.3 months \\
D & 0.34 \\
E & 0.31 \\
F & 0.82 \\
G & 0.9 \\
1 year "ROI-DC" & $20 \%$ \\
\hline
\end{tabular}

This example shows that the company could think about BIM design program investment only if it is able to pay $2200 €$ per month to the engineer.

Figure 6 shows the ROI (\%) dependence on the wage ( $€ /$ month). The linear relationship is evident. Software configurations with the BIM design option are compared. The comparison reveals that the less expensive alternative I ROI is negative at $-31.41 \%$, while the more expensive alternative III scores $-61.16 \%$ (assuming the average wage as reported by the Lithuanian Department of Statistics). Cheaper program one year ROI is possible at $2740 € /$ month wages, meanwhile, the more expensive program -at $5100 € /$ month. It shows that the turning point $(\mathrm{ROI}=0 \%)$ choosing alternative $\mathrm{I}$ is at $1104 € /$ month wage, meanwhile, the turning point $(\mathrm{ROI}=0 \%$ ) of the more expensive alternative is at $2055 € /$ month.

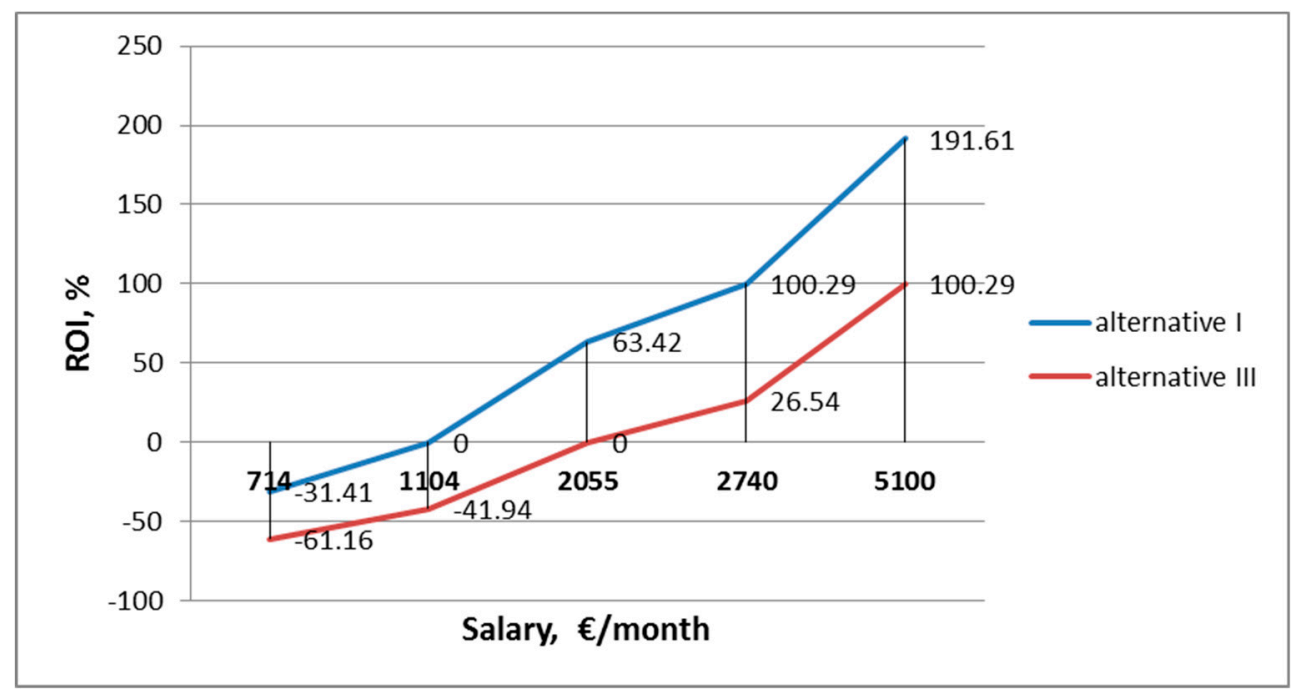

Figure 6. ROI dependence on monthly labor cost.

The obtained results of the ROI assessments of BIM programs reflect the current construction market situation where the salaries of specialists do not follow the market reality. ROI in BIM programs is not just equal to zero, but is negative. It is revealing that the dependence is not completely linear. Raising the salary of the employee by 1.55 times $(714 € \rightarrow 1104 €)$ at the alternative I and by 2.88 times $(714 € \rightarrow 2055 €)$ at the alternative III, ROI $=0 \%$ is obtained. This means no first year ROI but it is likely that in the same situation of a company next year ROI will be positive.

For the possibility of the first year ROI $=100 \%$ of BIM programs the salary of the alternative I should be $2740 € /$ month and $5100 € /$ month salary for the alternative III.

Figure 7 shows ROI (\%) dependence on the gross wage ( $€ /$ month). The relationship is very strong $\left(R^{2}=0.9893\right.$ and $\left.R^{2}=0.9873\right)$. 


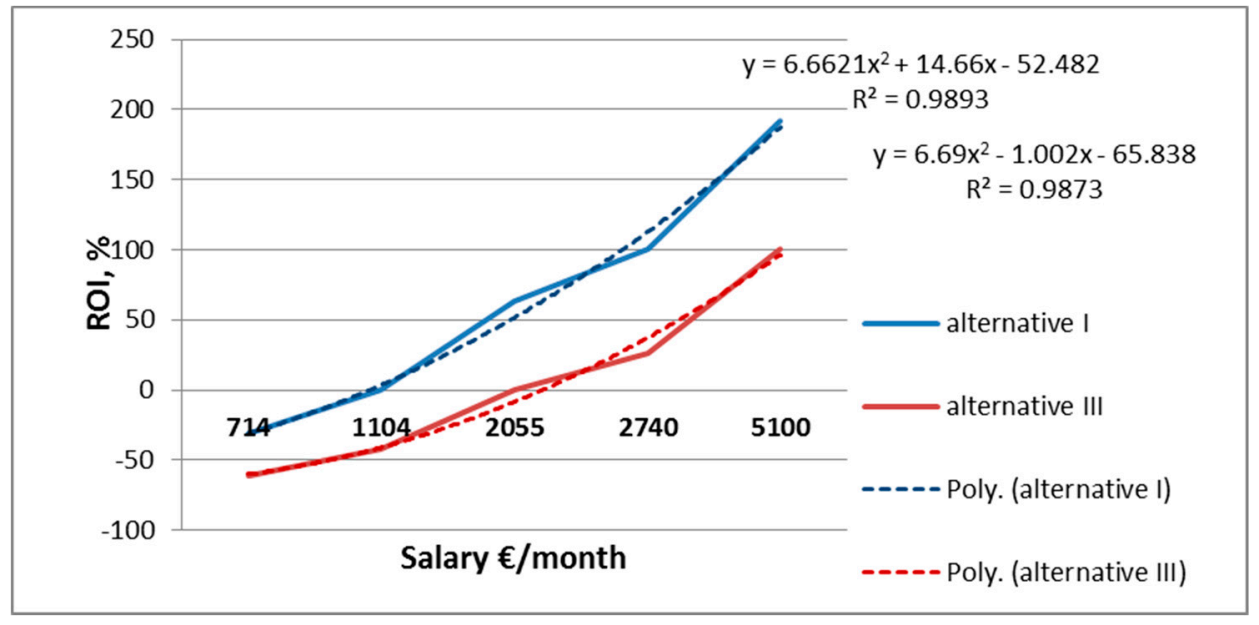

Figure 7. Strength evaluation of statistical relationship.

Strong statistical relationship established by assessing the link between ROI and average wage is described, respectively, by the exponential regression model. Results of both I and II alternatives lead to the conclusion that-in the state of low average wages-a higher ROI is possible only with necessary higher wage growth. With high wages, similar wage increase will affect ROI growth.

\section{Conclusions}

The presented study is based not only on theoretical considerations and examples present in scientific literature, but also on the interviews with project staff engaged in BIM-based design in 10 enterprises. ROI-DC method is a conceptual computational model in which the Return on Investment formula is adjusted to the design process in construction projects. It is important to remember that the calculation of the ROI-DC coefficients should be carried out on the case-by-case basis.

The developed ROI-DC calculation method evaluates additional variables (direct design work and company's specificity), influencing the return on investment in BIM technologies. The calculations have shown that it takes time for the ROI in BIM technology to achieve positive figures. The following conclusions may be drawn:

1. The calculations have shown that the ROI of the $4500 €$ program is possible in five years if the service prices rise about two times (employee salary growth: $714 € \rightarrow 1375 €$ ).

2. Estimated BIM software installation for the architect workplace may provide the first year $\mathrm{ROI}=20 \%$ under the following conditions. Company's service prices should rise about two times $(714 € \rightarrow 1380 €)$ in case of the less expensive design program and up to four times (714 $€ \rightarrow 2560 €)$ when the more expensive design program is chosen.

3. Estimated BIM software installation for the engineer constructor workplace may provide the first year ROI $=20 \%$ under the following conditions. It is worth for a company to invest in BIM design program, only when company is able to pay $2200 €$ monthly salary to an engineer (respectively, service prices will increase three times: $714 € \rightarrow 2200 €)$.

4. ROI (\%) dependence on the gross wage ( $€$ /month) is almost linear. Alternatives of programs with the BIM design program possibility are compared. Less expensive program would yield ROI within one year only with the $2740 €$ /month employee's salary; the more expensive program—with the $5100 € /$ month salary.

The relationship between the ROI $(\%)$ and the gross wage $\left(€ /\right.$ month) is very strong $\left(R^{2}=0.9893\right.$ and $R^{2}=0.9873$ ). There is a strong statistical dependence. With high wages increase ROI is accordingly higher. 
In conclusion, the proposed ROI-DC method may be seen as a practical management instrument [60], facilitating economically rational decisions in the sector, thus increasing its productivity [60]. The results of the calculations indicate that BIM adoption may suffer a significant slowdown for purely economic reasons. Therefore, if one counts on a quicker and more substantial contribution of BIM to the sustainability of the construction sector, isomorphic pressures from policy circles, regulatory bodies, and industry associations to adopt BIM on the project level are needed [61]. Local authorities in many countries are committed to BIM and require that all new public projects be carried out with use of BIM. It is done with the assumption that when project owners see the benefits of BIM-based asset management BIM would be free-willingly implemented by private actors from the earliest project stages.

Policy interventions might be combined with various financial and non-financial incentives to adopt BIM by designers who would otherwise choose not to do it for economic reasons. Moreover, high positive sustainability-related externalities that are offered by BIM justify a concerted effort of public and private stakeholders to apply BIM more extensively to construction of objects other that buildings (roads, bridges, engineering objects, line infrastructure) [62].

Acknowledgments: Part of the research for this paper has been conducted in the framework of projects no. S/WZ/1/2014 and S/WZ/4/2015 financed from the funds of the Ministry of Science and Higher Education of Poland.

Author Contributions: All the authors contribute equally to this paper.

Conflicts of Interest: The authors declare no conflict of interest.

\section{References}

1. Wong, K.-D.; Fan, Q. Building information modelling (BIM) for sustainable building design. Facilities 2013, 31, 138-157. [CrossRef]

2. Giel, B.K.; Issa, R.; Olbina, S. Return on investment analysis of building information modeling in construction. In Proceedings of the International Conference on Computing in Civil and Building Engineering; Tizani, W., Ed.; University of Florida: Gainesville, FL, USA, 2010. Available online: http://www.engineering.nottingham.ac.uk/icccbe/proceedings/pdf/pf77.pdf (accessed on 8 February 2018).

3. Sen, S. The Impact of BIM/VDC on ROI: Developing a Financial Model for Savings and ROI Calculation of Construction Projects. Master's Thesis, Royal Institute of Technology, Stockholm, Sweden, 2012.

4. The Business Value of BIM for Construction in Global Market; Smart Market Report; McGraw Hill Construction: Bedford, MA, USA, 2008.

5. The Business Value of BIM for Construction in Global Market; Smart Market Report; McGraw Hill Construction: Bedford, MA, USA, 2009.

6. The Business Value of BIM for Construction in Global Market; Smart Market Report; McGraw Hill Construction: Bedford, MA, USA, 2010.

7. The Business Value of BIM for Construction in Global Markets; Smart Market Report; McGraw Hill Construction: Bedford, MA, USA, 2014.

8. Santos, R.; Costa, A.A.; Grilo, A. Bibliometric analysis and review of Building Information Modelling literature published between 2005 and 2015. Autom. Construct. 2017, 80, 118-136. [CrossRef]

9. Hu, Z.-Z.; Zhang, J.-P.; Yu, F.-Q.; Tian, P.-L.; Xiang, X.-S. Construction and facility management of large MEP projects using a multi-Scale building information model. Adv. Eng. Softw. 2016, 100, 215-230. [CrossRef]

10. Miettinen, R.; Paavola, S. Beyond the BIM utopia: Approaches to the development and implementation of building information modeling. Autom. Construct. 2014, 43, 84-91. [CrossRef]

11. Love Peter, E.D.; Matthews, J.; Simpson, I.; Hill, A.; Olatunji, O.A. A benefits realization management building information modeling framework for asset owners. Autom. Construct. 2014, 37, 1-10. [CrossRef]

12. Kim, H.; Anderson, K.; Lee, S.; Hildreth, J. Generating construction schedules through automatic data extraction using open BIM (building information modeling) technology. Autom. Construct. 2013, 35, 285-295. [CrossRef] 
13. Migilinskas, D.; Ustinovichius, L. Computer-aided modelling, evaluation and management of construction project according PLM concept. Lect. Notes Computer Sci. 2006, 4101, 242-250. [CrossRef]

14. Popov, V.; Juocevicius, V.; Migilinskas, D.; Ustinovichius, L.; Mikalauskas, S. The use of a virtual building design and construction model for developing an effective project concept in 5D environment. Autom. Construct. 2010, 19, 357-367. [CrossRef]

15. Future directions for IFC-based interoperability. Available online: http:/ / www.itcon.org/2003/17 (accessed on 8 February 2018).

16. Ding, L.; Zhou, Y.; Akinci, B. Building information modeling (BIM) application framework: The process of expanding from 3D to computable nD. Autom. Construct. 2014, 46, 82-93. [CrossRef]

17. Ustinovičius, L.; Rasiulis, R.; Nazarko, L.; Vilutienè, T.; Reizgevicius, M. Innovative research projects in the field of building lifecycle management. Procedia Eng. 2015, 122, 166-171. [CrossRef]

18. Ustinovičius, L.; Walasek, D.; Rasiulis, R.; Cepurnaite, J. Wdrażanie technologii informacyjnych w budownictwie-Praktyczne studium przypadku. Econ. Manag. 2015, 1, 290-310. [CrossRef]

19. Azhar, S.; Carlton, W.A.; Olsen, D.; Ahmad, I. Building information modeling for sustainable design and LEED®rating analysis. Autom. Construct. 2011, 20, 217-224. [CrossRef]

20. Kibert, C.J. Sustainable Construction: Green Building Design and Delivery, 4th ed.; John Wiley \& Sons, Inc.: Hoboken, NJ, USA, 2016; p. 23.

21. BIM and Sustainable Design. Available online: http://buildipedia.com/aec-pros/design-news/bim-andsustainable-design (accessed on 27 December 2017).

22. Yan, H.; Damian, P. Benefits and Barriers of Building Information Modelling. In Proceedings of the 12th International Conference on Computing in Civil and Building Engineering, Beijing, China, 16-18 October 2008.

23. Aladag, H.; Demirdögen, G.; Isık, Z. Building information modeling (BIM) use in Turkish construction industry. Procedia Eng. 2016, 161, 174-179. [CrossRef]

24. Jia, J.; Sun, J.; Wang, Z.; Xu, T. The construction of BIM application value system for residential buildings' design stage in China based on traditional DBB mode. Procedia Eng. 2017, 180, 851-858. [CrossRef]

25. Ma, S.; Li, C.; Hu, D.; Zhao, Q.; Zhang, X. The application of BIM technology in construction management. J. Residuals Sci. Technol. 2016, 13. [CrossRef]

26. Zhang, J.; Seet, B.-C.; Lie, T.T. Building information modelling for smart built environments. Buildings 2015, 5, 100-115. [CrossRef]

27. Tulenheimo, R. Challenges of implementing new technologies in the world of BIM: Case study from construction engineering industry in Finland. Procedia Econ. Finance 2015, 21, 469-477. [CrossRef]

28. Lin, Y.-C.; Lee, H.-Y.; Yang, I.-T. Developing as-built BIM model process management system for general contractors: A case study. J. Civil Eng. Manag. 2016, 22, 608-621. [CrossRef]

29. Zuo, J.; Zillante, G.; Xia, B.; Chan, A.; Zhao, Z. How Australian construction contractors responded to the economic downturn. Int. J. Strat. Property Manag. 2015, 19, 245-259. [CrossRef]

30. Ning, G.; Junnan, L.; Yansong, D.; Zhifeng, Q.; Qingshan, J.; Weihua, G.; Geert, D. BIM-based PV system optimization and deployment. Energy Build. 2017, 150, 13-22. [CrossRef]

31. Bradley, A.; Li, H.; Lark, R.; Dunn, S. BIM for infrastructure: An overall review and constructor perspective. Autom. Construct. 2016, 71, 139-152. [CrossRef]

32. Petri, I.; Beach, T.; Rana, O.F.; Rezgui, Y. Coordinating multi-site construction projects using federated clouds. Autom. Construct. 2017, 83, 273-284. [CrossRef]

33. Porwal, A.; Hewage, K.N. Building information modeling (BIM) partnering framework for public construction projects. Autom. Construct. 2013, 31, 204-214. [CrossRef]

34. Guidelines for Digital Construction in Lithuania 2014-2020. Available online: http://www. skaitmeninestatyba.lt/files/On_development_of_BIM_and_Digital_Construction_Lithuania.pdf (accessed on 23 March 2014).

35. Čereška, A.; Zavadskas, E.K.; Cavallaro, F.; Podvezko, V.; Tetsman, I.; Grinbergienè, I. Sustainable assessment of aerosol pollution decrease applying multiple attribute decision-making methods. Sustainability 2016, 8, 586. [CrossRef]

36. Zolfani, S.H.; Maknoon, R.; Zavadskas, E.K. Multiple attribute decision making (MADM) based scenarios. Int. J. Strat. Property Manag. 2016, 20, 101-111. [CrossRef] 
37. Książek, M.V.; Nowak, P.O.; Kivrak, S.; Rosłon, J.H.; Ustinovichius, L. Computer-aided decision-making in construction project development. J. Civil Eng. Manag. 2015, 21, 248-259. [CrossRef]

38. Bucoń, R.; Sobotka, A. Decision-making model for choosing residential building repair variants. J. Civil Eng. Manag. 2015, 21, 893-901. [CrossRef]

39. Suder, A.; Kahraman, C. Multicriteria analysis of technological innovation investments using fuzzy sets. Technol. Econ. Dev. Econ. 2016, 22, 235-253. [CrossRef]

40. Cid-López, A.; Hornos, M.J.; Carrasco, R.A.; Herrera-Viedma, E. A hybrid model for decision-making in the information and communications technology sector. Technol. Econ. Dev. Econ. 2015, 21, 720-737. [CrossRef]

41. Hattab, M.; Hamzeh, F. Using social network theory and simulation to compare traditional versus BIM-lean practice for design error management. Autom. Construct. 2015, 52, 59-69. [CrossRef]

42. Cao, D.; Wang, G.; Li, H.; Skitmore, M.; Huang, T.; Zhang, W. Practices and effectiveness of building information modelling in construction projects in China. Autom. Construct. 2015, 49, 113-122. [CrossRef]

43. Poirier, E.A.; Staub-French, S.; Forgues, D. Measuring the impact of BIM on labor productivity in a small specialty. Autom. Construct. 2015, 58, 74-84. [CrossRef]

44. Azhar, S. Building information modeling (BIM): Trends, benefits, risks, and challenges for the AEC industry. Leader. Manag. Eng. 2011, 11, 241-252. [CrossRef]

45. Walasek, D.; Barszcz, A. Analysis of the adoption rate of building information modeling [BIM] and its return on investment [ROI]. Procedia Eng. 2017, 172, 1227-1234. [CrossRef]

46. Al-Zwainy, F.M.S.; Mohammed, I.A.; Al-Shaikhli, K.A.K. Diagnostic and assessment benefits and barriers of BIM in construction project management. Civ. Eng. J. Tehran 2017, 3, 63-77.

47. Johansson, M.; Roupé, M.; Bosch-Sijtsema, P. Real-time visualization of building information models (BIM). Autom. Construct. 2015, 54, 69-82. [CrossRef]

48. Giel, B.; Issa, R. Return on investment analysis of using building information modeling in construction. J. Comput. Civ. Eng. 2013, 27, 511-521. [CrossRef]

49. Love, P.; Simpson, I.; Hill, A.; Standing, C. From justification to evaluation: Building information modeling for asset owners. Autom. Construct. 2013, 35, 208-216. [CrossRef]

50. Jin, R.; Hancock, C.M.; Tang, L.; Wanatowski, D. BIM investment, returns, and risks in China's AEC industries. J. Const. Eng. Manag. 2017, 143. [CrossRef]

51. Gu, Y.; Storey, V.C.; Woo, C.C. Conceptual modeling for financial investment with text mining. Lect. Notes Comput. Sci. 2015, 9381, 528-535. [CrossRef]

52. Won, J.; Lee, G. How to tell if a BIM project is successful: A goal-driven approach. Autom. Construct. 2016, 69, 34-43. [CrossRef]

53. Barlish, K.; Sullivan, K. How to measure the benefits of BIM: A case study approach. Autom. Construct. 2012, 24, 149-159. [CrossRef]

54. Lee, G.; Park, H.K.; Won, J. D-3 city project: Economic impact of BIM-assisted design validation. Autom. Construct. 2012, 22, 577-586. [CrossRef]

55. Calculating BIM's Return on Investment. Available online: http://www.cadalyst.com/aec/calculatingbim039s-return-investment-2858 (accessed on 20 February 2018).

56. Return on Investment with Autodesk Revit. Autodesk Building Solutions White Paper. Available online: http:/ / usa.autodesk.com/revit/white-papers/ (accessed on 15 April 2015).

57. Chi, H.-L.; Wang, X.; Jiao, Y. BIM-enabled structural design: Impacts and future developments in structural modelling, analysis and optimisation processes. Arch. Comput. Methods Eng. 2015, 22, 135-151. [CrossRef]

58. Ashcraft, H.; Shelden, R.D. BIM Implementation Strategies, Hanson Bridgett, Gehry Technologies, 2015. Available online: http:/ / www.nibs.org/?page=bsa_proceedings (accessed on 10 March 2015).

59. Reizgevičius, M.; Reizgevičiūte, L.; Ustinovičius, L. The need of BIM technologies implementation to design companies. Econ. Manag. 2015, 7, 45-53. [CrossRef]

60. Ejdys, J.; Matuszak-Flejszman, A. New management systems as an instrument of implementation sustainable development concept at organizational level. Technol. Econ. Dev. Econ. 2010, 16, 202-218. [CrossRef] 
61. Nazarko, J.; Chodakowska, E. Measuring productivity of construction industry in Europe with data envelopment analysis. Procedia Eng. 2015, 122, 204-212. [CrossRef]

62. Radziszewski, P.; Nazarko, J.; Vilutiene, T.; Dębkowska, K.; Ejdys, J.; Gudanowska, A.; Halicka, K.; Kilon, J.; Kononiuk, A.; Kowalski, J.K. Future trends in road technologies development in the context of environmental protection. Baltic J. Road Bridge Eng. 2016, 11, 160-168. [CrossRef] 